\title{
Merancang Model dan Media Pembelajaran Online untuk Pengajaran Matematika di Pendidikan Tinggi
}

\author{
Arbain $^{1 *}$, \& Salim ${ }^{2}$ \\ ${ }^{1,2}$ Universitas Sembilanbelas November Kolaka, Kolaka, Indonesia
}

\section{INFO ARTICLES}

Article History:

Received: 07-11-2021

Revised: 26-12-2021

Approved: 27-12-2021

Publish Online: 31-12-2021

\section{Key Words:}

Model and Media Design; Virtual Flipped Classroom Model; Online Mathematics Learning,

\begin{abstract}
This study aims to design learning models and media to solve problems caused by the lack of good interaction and online learning experiences for students during the Covid-19 pandemic. The design and development of models and media are carried out by referring to the ADDIE model which consists of five stages, namely the analysis, design, development, implementation and evaluation stages. The resulting product is a virtual flipped classroom model and 10 interactive learning videos with a duration of 20 to 25 minutes. The product validity based on the evaluation results from two experts was obtained valid. Students gave a positive response to the lecture process with the VFC approach and the use of video as a learning resource. The results of practicality analysis obtained practical products. Likewise with the assessment of the effectiveness aspect, the calculation results show an effective product with a very good category. The models and media produced are in accordance with the needs of students and act as alternative solutions in online lectures that are not monotonous.
\end{abstract}

\begin{abstract}
Abstrak: Penelitian ini bertujuan merancang model dan media pembelajaran untuk memecahkan masalah yang disebabkan oleh kurang baiknya interaksi dan pengalaman belajar online mahasiswa selama masa pandemi Covid-19. Perancangan dan pengembangan model dan media dilakukan dengan merujuk pada model ADDIE yang terdiri atas lima tahapan, yaitu tahap analisis, desain, pengembangan, implementasi dan evaluasi. Produk yang dihasilkan berupa model virtual flipped classroom dan 10 video pembelajaran interaktif dengan durasi 20 sampai 25 menit. Validitas produk berdasarkan hasil evaluasi dari dua ahli diperoleh valid. Mahasiswa memberikan respon positif terhadap proses perkuliahan dengan pendekatan VFC dan pemanfaatan video sebagai sumber belajar. Hasil analisis praktikalitas diperoleh produk praktis. Demikian juga dengan penilaian pada aspek efektifitas, hasil perhitungan menunjukkan produk efektif dengan kategori sangat baik. Model dan media yang dihasilkan sesuai dengan kebutuhan mahasiswa dan berperan sebagai alternatif solusi dalam perkuliahan online yang tidak monoton.
\end{abstract}

Correspondence Address: Jln. Pemuda No. 15 Kolaka, Kabupaten Kolaka, Sulawesi Tenggara, Indonesia, Kode Pos 93517; e-mail: arbaindjingga@gmail.com

How to Cite (APA $6^{\text {th }}$ Style): Arbain, A., \& Salim, S. (2021). Merancang Model dan Media Pembelajaran Online untuk Pengajaran Matematika di Pendidikan Tinggi. JKPM (Jurnal Kajian Pendidikan Matematika), 7(1): 121-134. http://dx.doi.org/10.30998/jkpm.v7i1.11313

Copyright: 2021 Arbain Arbain, Salim Salim

Competing Interests Disclosures: The authors declare that they have no significant competing financial, professional or personal interests that might have influenced the performance or presentation of the work described in this manuscript. 


\section{PENDAHULUAN}

Mewabahnya corona virus disease (Covid-19) yang melanda banyak negara di dunia melahirkan berbagai tantangan di berbagai bidang, tidak terkecuali bidang pendidikan (Wiratomo \& Mulyatna, 2020). Fenomena wabah Covid-19 telah mentransfomasi dan menggeser pedagogis dari metode tradisional ke pendekatan pembelajaran modern secara spontan di berbagai level Pendidikan, dari kelas tatap muka ke kelas virtual, dari seminar ke webinar (Firman \& Rahayu, 2020). Sebelumnya, pembelajaran jarak jauh secara populer dianggap sebagai bagian dari pendidikan nonformal, tetapi saat ini, tampaknya secara bertahap akan menggantikan sistem pendidikan formal jika keadaan terus berlanjut dari waktu ke waktu (Patricia, 2020).

Dalam iklim perubahan tersebut, ekosistem baru ini membutuhkan instruktur yang tidak hanya memiliki pengetahuan luas di banyak bidang tetapi juga inovatif dan mudah beradaptasi dengan perubahan keadaan serta mampu menyalurkannya kepada peserta didik (Mulyatna, et. al., 2021). Seorang instruktur tidak hanya perlu menyediakan konten pembelajaran bagi pelajarnya dalam pembelajaran online, tetapi juga perlu untuk mengorganisasikan pembelajaran agar pelajar mampu mengakses, mengeksplorasi, dan memahami konten tersebut (Hodges, et. al., 2020). Interaksi yang berlansung antara pelajar dan instruktur serta desain lingkungan belajar dalam lingkungan virtual yang dimediasi oleh teknologi dapat memiliki pengaruh yang besar terhadap hasil belajar (Gonzalez, et. al., 2020)

Beberapa tantangan telah dilaporkan dalam penelitian baru-baru ini, bahwa pembelajaran online memerlukan banyak waktu dan fleksibilitas sehingga peserta didik tidak punya waktu yang cukup untuk melakukannya (Dhawan, 2020). Perhatian pribadi juga merupakan masalah besar yang dihadapi pada pembelajaran online (Mishra, et. al., 2020). Peserta didik menginginkan interaksi dua arah yang terkadang sulit diterapkan. Proses pembelajaran tidak dapat mencapai potensi penuhnya sampai peserta didik mempraktikkan apa yang mereka pelajari. Terkadang, konten online semuanya bersifat teoritis dan tidak membiarkan peserta didik berlatih dan belajar secara efektif. Konten kursus yang biasa-biasa saja juga merupakan masalah utama. Pelajar merasa bahwa kurangnya komunitas, masalah teknis, dan kesulitan dalam memahami tujuan instruksional merupakan hambatan utama untuk pembelajaran online.

Pengalaman belajar serta interaksi yang kurang baik pada pembelajaran online menyebabkan mahasiswa cenderung kesulitan memahami materi secara tuntas terutama materi yang sifatnya abstrak seperti matematika (Firman \& Rahayu, 2020; Arbain \& Farman, 2021). Hasil refleksi mengajar dan wawancara dengan mahasiswa ditemukan masalah utama yang menjadi kendala perkuliahan online, yaitu mahasiswa cenderung kesulitan memahami materi perkuliahan secara holistik karena keterbatasan waktu. Materi perkuliahan yang disajikaan saat mulai kelas virtual yang direncanakan dalam satu kali pertemuan seringkali tidak selesai dibahas dan didiskusikan karena dosen mengikuti ritme mahasiswa yang lambat menyerap materi. Hal ini berdampak pada ketidaktercapaian tujuan pembelajaran matematika sebagaimana yang diharapkan. Padahal, matematika sebagai mata pelejaran penting yang dibutuhkan oleh semua bidang ilmu. Pembelajaran matematika harus mampu memberikan keterampilan dasar berpikir guna mengembangkan keterampilan berpikir kritis, kreatif, dan inovatif mahasiswa.

Mencermati hal tersebut, penting bagi dosen untuk merancang dan mengupayakan lingkungan belajar matematika online yang mampu mengarahkan dan menggerakkan mahasiswa untuk berpartisipasi aktif, interaktif dan bertanggung jawab terhadap pembelajarannya sendiri melalui berbagai kegiatan (Wiratomo \& Mulyatna, 2020). Salah satu pendekatan pembelajaran matematika yang efisien untuk mencapai pembelajaran aktif, baik di dalam maupun di luar kelas adalah flipped classroom (Szarek, et. al., 2016). Strategi flipped classroom menfasilitasi pengajaran dan pembelajaran dengan membalik perkuliahan dan pekerjaan rumah dalam video multimedia yang diposting online sehingga mahasiswa dapat melihat dan mempelajarinya sebanyak yang mereka suka sebelum kelas dimulai (Ridha, et. al., 2016). Video-video ini dapat 
diproduksi sendiri oleh dosen atau dikumpulkan dari situs berbagi video yaitu YouTube, Khan Academy, dan PresentationTube. Pendekatan flipped classroom menerapkan konsep membalik kelas di mana konten pembelajaran berupa teks dan video diberikan kepada pelajar sebelum masuk kelas sehingga pelajar dapat mepelajari materi terlebih dahulu sebelum masuk kelas, sedangkan kelas tatap muka digunakan untuk mengkonsolidasikan pengetahuan melalui diskusi, mengerjakan tugas, presentasi, dan kegiatan kolaboratif lain (Chandra \& Nugroho, 2016). Pelajar dan instruktur akan mendapatkan keuntungan dari penerapan strategi flipped classroom. Pelajar dapat membaca teks atau menyimak video secara berulang sesuai kebutuhan dan memanfaatkan kelas tatap muka untuk mengeksplorasi pengetahuannya sedangkan instruktur dapat mendukung pelajar untuk menjadi pembelajar mandiri, meningkatkan pemikiran kritis, membangun pengalaman, mengembangkan keterampilan komunikasi dan kerjasama, serta meningkatkan motivasi belajar (Sun, et. al., 2017).

Beberapa penelitian sebelumnya yang menggunakan strategi flipped classroom sebagimana yang telah dikemukakan masih diterapkan pada kelas tatap muka lansung, belum ada yang memberlakukan pada tatap muka secara virtual (Lo, et. al., 2017; Lai \& Hwang, 2016; Saunders, 2014). Pada penelitian ini, penggunaan strategi flipped classroom tidak dilakukan dalam kelas tatap muka lansung, tetapi diterapkan pada kelas tatap muka virtual. Jarak sosial akibat wabah Covid-19 telah merubah kelas tatap muka menjadi kelas virtual. Karena itu, Strategi pembelajaran virtual classroom menjadi salah satu perhatian dalam penelitian ini.

Virtual classroom dapat didefinisikan sebagai lingkungan berbasis komputer di mana pembelajaran aktif dapat diterapkan karena hampir semua yang dapat dilakukan di ruang kelas nyata dapat dilakukan di ruang kelas virtual. Peran instruktur dalam virtual classroom tidak jauh berbeda dengan di kelas sebenarnya. Pelajar dan instruktur dapat berkolaborasi menggunakan berbagai saluran komunikasi seperti audio, video, obrolan, dan papan tulis. Lingkungan virtual classroom memberi pelajar dan instruktur kemungkinan untuk berkomunikasi baik secara sinkron maupun asinkron. Lingkungan sinkronisasi virtual classroom secara efektif meningkatkan kepuasan mahasiswa dan berpengaruh pada sisi sosial pendidikan (Thomson, 2010). Selain itu, menggunakan virtual classroom sinkron memberi pelajar kesempatan untuk: berinteraksi dengan instruktur dan pelajar lain, memperoleh umpan balik langsung dari isntruktur, meningkatkan interaksi dinamis dengan peserta lain, memperkuat kehadiran sosial mereka, bertukar dukungan emosional, dan membangun komunikasi (Martin, et. al., 2012).

Berdasarkan uraian tersebut, penelitian ini bertujuan merancang model dan media pembelajaran online untuk memecahkan masalah yang disebabkan oleh kurang baiknya interaksi dan pengalaman belajar online mahasiswa. Perancangan model dilakukan dengan mengintegrasikan konsep flipped classroom dan virtual classroom. Model pembelajaran baru ini dinamakan virtual flipped classroom. Untuk mendukung penerapan model baru tersebut, penelitian ini juga merancang media pembelajaran berupa video yang akan digunakan pada proses pembelajaran. Tujuan akhirnya adalah menghasilkan model dan media berupa video yang valid, praktis, dan efektif.

\section{METODE}

Penelitian ini menggunakan desain penelitian dan pengembangan model ADDIE. ADDIE merupakan model yang menyajikan tahapan dasar pembelajaran yang sederhana dan mudah dipelajari, yang terdiri dari analisis, desain, pengembangan, implementasi, dan evaluasi (Gümüş, 2010). Dengan model ADDIE, penelitian ini akan memberikan desain yang baik dan menghasilkan model pembelajaran baru yang efektif. Model penelitian ADDIE mampu memaksimalkan peran model dan media pembelajaran yang valid yang terdiri dari tahapan penelitian dan pengembangan sistematis yaitu analisis, desain, pengembangan, implementasi, dan evaluasi (Feriatna, et. al., 
2017; Aldoobie, 2015). Tahapan-tahapan model ADDIE disajikan pada Gambar 1., yang diadaptasi dari instructional media design (Lee \& Owens, 2012).

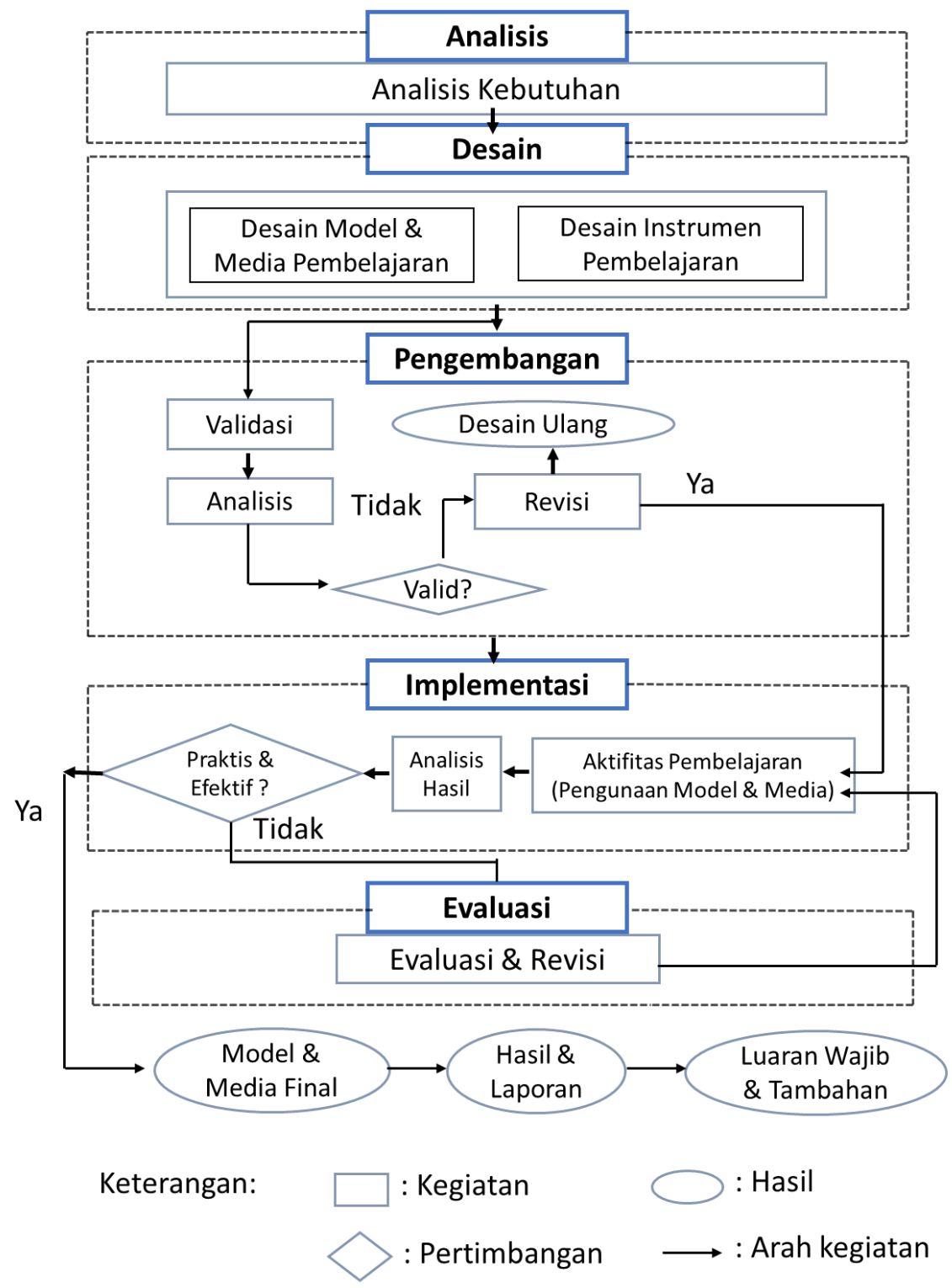

Gambar 1. Prosedur Penelitian

Prosedur penelitian pada Gambar 1. kemudian dijelaskan berdasarkan tahap analisis, tahap desain, tahap pengembangan, tahap implementasi dan tahap evaluasi. Pertama, tahap analisis dilakukan untuk memperoleh gambaran kebutuhan mahasiswa selama kegiatan belajar online masa pandemi Covid-19. Kegiatan yang dilakukan pada tahap ini antara lain refleksi mengajar online, observasi proses pembelajaran dan wawancara dengan mahasiswa dan dosen untuk memperoleh informasi mengenai masalah dalam pembelajaran matematika secara online serta telaah artikel terkait dan konsep yang relevan. Hasil analisis selanjutnya digunakan untuk mendefinisikan kebutuhan pembelajaran matematika online.

Kedua, tahapan desain yaitu mengaktualisasikan kebutuhan pembelajaran matematika online yang telah didefinisikan pada tahap analisis berupa mendesain produk. Kegiatan yang dilakukan terdiri dari pembuatan konsep model pembelajaran, penyusunan konten pembelajaran, pembuatan video dan penyiapan feedback. Pada tahapan ini juga disusun lembar validasi, kuisioner respon mahasiswa, dan tes hasil belajar. 
Ketiga, setelah tahap desain, suatu produk dikembangkan dan dimanfaatkan. Kegiatan yang dilakukan meliputi pembuatan produk dan validasi ahli. Validasi ahli dilakukan untuk menampung masukan, koreksi, dan perbaikan terhadap produk yang dihasilkan. Hasil evaluasi produk oleh validator digunakan untuk menyempurnakan produk. Tim validator terdiri dari 2 orang dosen dengan masing-masing bidang keahlian pengajaran matematika dan pengembangan perangkat pembelajaran.

Keempat, tahap implementasi, yaitu melakukan uji coba model dan media pembelajaran dalam suatu aktivitas pembelajaran dalam kelas virtual untuk mengetahui keefektifan model. Subjek uji coba adalah mahasiswa Prodi. Pendidikan Matematika USN Kolaka yang mengikuti mata kuliah matematika diskrit pada Tahun Akademik 2020/2021 yang terdiri dari 16 orang. Setelah belajar, siswa mengisi kuesioner dan mengerjakan soal posttest.

Kelima, tahap evaluasi dilakukan untuk memastikan produk yang dikembangkan sudah sesuai dengan yang diharapkan dan tujuan yang ingin dicapai atau perlu direvisi. Kegiatan yang dilakukan meliputi revisi produk (jika ada) dan refleksi implementasi. Hal ini bertujuan untuk menganalisis saran validator serta kendala yang dihadapi mahasiswa dan dosen dalam proses perkuliahan menggunakan model VFC dan media video yang telah dihasilkan.

Instrumen yang digunakan dalam penelitian ini terdiri atas lembar atau pedoman validasi, kuisioner respon mahasiswa, dan tes hasil belajar. Lembar validasi terdiri atas dua, yaitu lembar validasi model dan lembar validasi video. Lembar validasi model disusun berdasarkan aspek penilaian antara lain: dasar teori model, analisis kebutuhan model, tujuan perancangan model, penjelasan dan karakterstik model, sistem evaluasi dan penilaian dalam model, dan target capaian model pembelajaran. Lembar validasi video disusun berdasarkan aspek: (1) kelayakan isi yang mencakup kesesuain materi, kelengkapan materi, kedalaman materi, keakuratan konsep dan prosedur, keakuratan contoh, keakuratan soal, keakuratan istilah-istilah, keakuratan notasi dan simbol, kualitas penjelasan, ketepatan bahasa, kesederhanaan bahasa, sistematika penyajian, dan interaksi penyajian dan (2) kelayakan tampilan yang meliputi kualitas gambar, kualitas suara, kualitas pencahayaan, keterbacaan teks, kemudahan pemutaran video, dan kemenarikan video.

Kuisioner respon mahasiswa terhadap proses perkuliahan disusun menjadi dua bagian. Bagian pertama bertujuan untuk memperoleh data praktikalitas mengenai model dengan indikator yang digunakan, yaitu aspek kebaruan model, aspek ketertarikan mahasiswa terhadap proses pembelajaran, dan minat mahasiswa. Bagian kedua dari kuisioner bertujuan untuk memperoleh data praktikalitas mengenai video pembelajaran yang disusun berdasarkan pernyataan: kemudahan pemutaran video, kejelasan teks pada video, kejelasan suara, kemudahan memahami bahasa yang digunakan, kemudahan memahami materi yang disampaikan, sistematika penjelasan materi, interaksi dalam penjelasan materi, kesesuaian materi pada video dengan materi perkuliahan, peran video dalam membantu proses belajar, peran video sebagai sumber belajar, peran video dalam memahami materi perkuliahan, peran video dalam mengulangi pelajaran, dan peran video untuk kemudahan dalam belajar. Adapun tes hasil belajar digunakan untuk memperoleh data mengenai hasil akademik mahasiswa setelah implementasi model pembelajaran. Tes hasil belajar disusun berdasarkan indikator: (1) mahasiswa mampu menjelaskan dan menggunakan kaidah dasar menghitung dan perluasannya dalam masalah kombinatorial; (2) mahasiswa mampu menjelaskan dan menggunakan teknik counting lanjut; dan (3) mahasiswa mampu menjelaskan permutasi dan kombinasi serta menggunakannya dalam memecahkan permasalahan terkait.

Dua instrumen, yaitu lembar validasi dan kuisioner respon mahasiswa menggunakan skala Likert dengan rincian seperti pada Tabel 1 .. 
Tabel 1. Skala Nilai Lembar Validasi dan Kuisioner Respon Mahasiswa

\begin{tabular}{cl}
\hline Skala Nilai & Kriteria \\
\hline 5 & Sangat baik \\
4 & Baik \\
3 & Cukup baik \\
2 & Kurang \\
1 & Sangat kurang \\
\hline
\end{tabular}

Sumber: diadobsi dari Sugiyono (2017)

Data yang diperoleh dari lembar validasi dan kuisioner respon mahasiswa dianalisis secara deskriptif menggunakan rumus Hasil Rating (HR) dan selanjutnya dilakukan pengkategorian dan interpretasi seperti pada Tabel 2. yang diadaptasi dari Hartono \& Irvandi, (2021). Pada penelitian ini, model pembelajaran ditetapkan memenuhi kriteria kevalidan dan kepraktisan apabila masuk pada kategori baik atau sangat baik.

$$
\mathrm{HR}=\frac{\text { Skor penilai }}{\text { Skor maksimal }} \times 100 \%
$$

\begin{tabular}{cl}
\multicolumn{2}{c}{ Tabel 2. Kriteria Hasil Rating } \\
\hline Hasil Rating $(\%)$ & Kriteria \\
\hline $84<\mathrm{HR} \leq 100$ & Sangat baik \\
$68<\mathrm{HR} \leq 84$ & Baik \\
$52<\mathrm{HR} \leq 68$ & Cukup baik \\
$36<\mathrm{HR} \leq 52$ & Kurang \\
$20 \leq \mathrm{HR} \leq 36$ & Sangat kurang \\
\hline
\end{tabular}

Sumber: Hartono \& Irvandi (2021)

Untuk mengetahui keefektifan model pembelajaran dilakukan analisis terhadap data hasil belajar mahasiswa dengan menghitung Hasil Rating (HR) Hartono \& Irvandi, (2021). Standar nilai yang digunakan mengacu pada sistem penilaian yang berlaku di USN kolaka. Pada penelitian ini ditetapkan nilai minimal 61, yaitu syarat nilai minimal kelulusan mata kuliah (nilai C). Hasil Rating (HR) dihitung dengan rumus sebagai berikut,

$$
\mathrm{HR}=\frac{\text { Jumlah mahasiswa yang memperoleh nilai } \geq 61}{\text { Jumlah mahasiswa peserta tes }} \times 100 \%
$$

Model dan media pembelajaran dikatakan efektif jika berada pada kategori baik atau sangat baik dengan mangacu pada kriteria Tabel 2. (Hartono \& Irvandi, 2021).

\section{HASIL}

Produk perancangan dalam penelitian ini berupa model dan media pembelajaran online. Hasil perancangan model berupa perpaduan model pembelajaran virtual classroom dan flipped classroom yang selanjutnya dinamakan model virtual flipped classroom. Adapun hasil perancangan media berupa video yang digunakan dalam proses pembelajaran virtual fliiped classroom. Berikut adalah hasil analisis model dan media berdasarkan model ADDIE.

Pada tahap analisis, kegiatan yang dilakukan berupa evaluasi diri dalam bentuk refleksi mengajar online, observasi proses pembelajaran dan wawancara dengan mahasiswa dan dosen serta telaah artikel terkait dan konsep yang relevan untuk memperoleh gambaran lengkap mengenai perkuliahan online. Beberapa temuan dari observasi dan refleksi mengajar antara lain: proses pembelajaran hanya sekedar migrasi dari tatap muka lansung ke tatap muka virtual dimana filosofi dan prinsip utama dari pembelajaran virtual belum diterapkan secara efektif; suasana kelas kurang interaktif dan cenderung satu arah; pemanfaatan video sebagai media dan sumber belajar 
masih minim; konten pembelajaran biasa-biasa saja dan bersifat teoritis serta kurang memberikan kesempatan kepada mahasiswa untuk berdiskusi, berlatih dan kerja-kerja kolaboratif lainnya. Hasil telaah artikel diperoleh bahwa pembelajaran matematika secara virtual asinkron dan minimnya pemanfaatan video berdampak pada ketidakpahaman mahasiwa tentang konsep matematika secara utuh (Firman \& Rahayu, 2020). Konten pembelajaran matematika online yang disajikan secara tekstual dan minim penjelasan verbal mempengaruhi pemahaman mahasiswa, di mana mahasiswa cenderung lambat memahami materi (Arbain \& Farman, 2021). Hasil wawancara dengan dosen dan mahasiswa menunjukkan bahwa mahasiswa membutuhkan waktu yang lebih banyak untuk memahami materi matematika pada pembelajaran virtual asingkron dibandingakan dengan pembelajaran tatap muka lansung, sehingga seringkali mahasiswa belum siap menerima materi lanjutan disebabkan materi sebelumnya belum dipahami secara utuh.

Temuan-temuan yang diperoleh selanjutnya dianalisis untuk mengidentifikasi kebutuhan mendasar dan utama mengenai konsep dan lingkungan pembelajaran online guna memperbaiki kualitas dan mutu pembelajaran. Berdasarkan analisis kebutuhan tersebut perlu dirancang model dan media pembelajaran yang dapat: memfasilitasi mahasiswa terlibat secara aktif dalam proses pembelajaran di kelas virtual dalam bentuk berlatih, presentasi, diskusi dan kerja kolaboratif lain; bertanggung jawab terhadap pembelajaran sendiri di luar kelas; dan menjadi solusi terhadap kendala keterlambatan memahami materi.

Kebutuhan pembelajaran matematika online yang telah didefinisikan pada tahap analisis diaktualisasikan dalam bentuk desain produk. Inilah proses yang dilalui dalam tahap desain. Kegiatan yang dilakukan terdiri dari pembuatan model pembelajaran, penyusunan konten pembelajaran, pembuatan video dan penyiapan feedback serta penyusunan lembar validasi, kuisioner respon mahasiswa, dan tes hasil belajar. Pembuatan konsep model pembelajaran dilakukan dengan memadukan konsep pembelajaran virtual classroom dan model pembelajaran flipped classroom. Model baru ini selanjuntnya dinamakan virtual flipped classroom (VFC), yaitu model pembelajaran yang dilakukan secara daring asinkron dan sinkron dengan tiga tahapan utama: (1) tahap belajar mandiri melalui daring asinkron, yaitu mahasiswa membaca materi dan menyimak video yang telah dibagikan dosen enam hari sebelum jadwal resmi; (3) mahasiswa mengerjakan umpan balik yang ada pada bagian akhir materi dan video sebagai tugas yang harus dipresentasikan saat masuk kelas; dan (3) tahap masuk kelas melalui daring sinkron, yaitu tatap muka secara virtual yang dimanfaatkan untuk mengkonsolidasikan pengetahuan awal mahasiswa dari kegiatan belajar mandiri dalam bentuk presentasi umpan balik, tanya jawab, diskusi kelas dan kelompok, serta kerja sama dalam menyelesaikan tugas. Desain Model VFC disajikan pada Gambar 2..

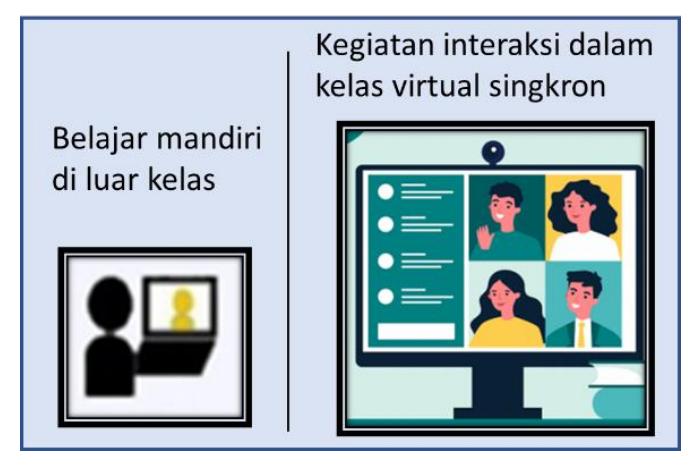

Gambar 2. Model Ruang Virtual Flipped Classroom

Pembuatan video pembelajaran dilakukan dalam dua tahapan sebagai berikut. Pertama, perencanaan yang terdiri atas pengenalan tujuan pembelajaran, menyiapkan konten pelajaran, dan menyiapkan perlatan yang akan digunakan untuk membuat video, serta melakukan pemetaan durasi untuk setiap video. Kedua, melakukan perekaman menggunakan perangkat lunak screen capture berbasis Open Broadcaster Software (OBS) untuk menghasilkan video. Video yang 
diproduksi sebanyak 10 video dengan durasi setiap video minimal 20 menit dan maksimal 25 menit. Durasi video dibuat cenderung singkat bertujuan untuk memudahkan akses mahasiswa terhadap video. Setiap video berisi tujuan pembelajaran, materi dan umpan balik. Adapun konten video mencakup materi kombinatorika, yaitu counting, permutasi dan kombinasi.

Tahap pengembangan merupakan kelanjutan dari tahap desain. Model yang telah didesain selanjutnya ditambahkan beberapa strategi pada tahap masuk kelas seperti presentasi, diskusi dan tanya jawab. Adapun video yang dihasilkan pada tahap desain dikembangkan dengan melakukan pengeditan dan penerbitan pada platform Youtube. Pengeditan video yang dilakukan berupa menghilangkan noise, menambahkan rekaman suara jika perlu, menambahkan efek, animasi, atau grafis, menghapus bagian yang tidak diinginkan, dan memperkecil ukuran video agar mudah diupload pada platform online. Tahap ini memerlukan waktu yang relatif lama. Setelah memastikan video berjalan dengan baik yang didukung dengan hasil validasi tim ahli langkah terakhir adalah penerbitan video pada platform Youtube.

Sebelum model dan media video diujicobakan dalam suatu aktivitas pembelajaran, terlebih dahulu divalidasi oleh tim ahli, yaitu dosen pendidikan matematika yang terdiri dari dua orang dengan keahlian masing-masing pengajaran matematika dan pengembangan perangkat pembelajaran. Hasil perhitungan validitas model dan media video disajikan secara berturut-turut pada Tabel 3. dan Tabel 4... Dari Tabel 3.. diperoleh hasil rating validitas model pembelajaran yang telah di rancang untuk validator 1 sebesar 83,33\% dan validator 2 sebesar 80,00\%. Berasarkan kriteria pada Tabel 2., maka dapat dinyatakan bahwa model pembelajaran VFC valid yaitu berada pada kategori baik. Untuk validitas media video pada Tabel 4. dapat dijelaskan bahwa pada aspek kelayakan isi, hasil rating dari validator 1 dan validator 2 berada pada kategori sangat baik dengan nilai masing-masing $84,62 \%$ dan $86,15 \%$. Demikian juga pada aspek kelayakan tampilan kedua validator memberikan penilaian sangat baik, yaitu 88,57\% untuk validator 1 dan $91,43 \%$ untuk validator 2. Dengan demikian, model VFC dan video pembelajaran layak untuk diujicobakan dalam suatu aktivitas pembelajaran virtual.

Tabel 3. Hasil Rating Validitas Model Pembelajaran

\begin{tabular}{ll}
\hline Validator & Hasil rating $(\%)$ \\
\hline Validator 1 & 83,33 \\
Validator 2 & 80,00 \\
Rata-rata & 81,67 \\
\hline
\end{tabular}

Sumber: diolah dari data penelitian, 2021

Tabel 4. Hasil Rating Validitas Video Pembelajaran

\begin{tabular}{lcc}
\hline \multirow{2}{*}{ Validator } & \multicolumn{2}{c}{ Hasil rating (\%) } \\
\cline { 2 - 3 } & Kelayakan isi & Kelayakan tampilan \\
\hline Validator 1 & 84,62 & 88,57 \\
Validator 2 & 86,15 & 91,43 \\
Rata-rata & 85,38 & 90,00 \\
\hline
\end{tabular}

Sumber: diolah dari data penelitian, 2021

Pada tahap implementasi dilakukan uji coba model VFC dan media video pembelajaran yang telah dirancang dan dikembangkan dalam suatu aktivitas pembelajaran virtual untuk mengetahui kepraktisan dan keefektifan model. Subjek uji coba adalah mahasiswa Prodi. Pendidikan Matematika USN Kolaka yang mengikuti mata kuliah Matematika Diskrit pada Tahun Akademik 2020/2021 yang terdiri dari 16 orang. Aplikasi kelas virtual yang digunakan adalah Google Classroom dan Zoom Meeting. Uji coba dilakukan dalam 3 (tiga) kali pertemuan, dengan setiap pertemuan dilakukan dalam tiga tahapan sebagai berikut. Pertama, dosen membagikan materi berupa teks dan hasil karya video pembelajaran kepada mahasiswa sebelum jadwal resmi perkuliahan (6 hari sebelum jadwal resmi) melalui aplikasi Google Classroom. Tahap ini bertujuan 
memfasilitasi mahasiswa untuk belajar mandiri dan mengkonstruksi sendiri pengetahuan yang mereka butuhkan. Kedua, mahasiswa mengerjakan umpan balik yang ada pada bagian akhir materi dan video sebagai tugas yang akan dipresentasikan saat masuk kelas. Ketiga, masuk kelas atau bertatap muka dalam kelas virtual sinkron menggunakan Zoom Meeting. Tahap ini digunakan untuk konsolidasi dan eksplorasi pengetahuan yang telah diperoleh mahasiswa pada tahap belajar mandiri dalam bentuk kegiatan presentasi laporan umpan balik, tanya jawab, dan diskusi antarmahasiswa dan mahasiswa dengan dosen. Dosen memberikan kesempatan kepada mahasiswa untuk bertanya tentang hal-hal yang menurut mereka masih perlu pendalaman dan memberikan kesempatan kepada mahasiswa lain menjawab. Jawaban dari mahasiswa yang masih kurang tepat dilengkapi oleh dosen. Pada tahap ini juga, dosen memberikan tugas kepada mahasiswa untuk dikerjakan dalam kelas secara kolaboratif.

Proses perkuliahan dengan model VFC dan menggunakan media video hasil karya dosen sebagai salah satu sumber belajar sebagaimana yang telah diuraikan berjalan dengan baik dan lancar. Dalam setiap video yang dibagikan terdapat umpan balik yang perlu dikerjakan oleh mahasiswa. Hasil pekerjaan umpan balik tersebut dievaluasi saat tatap muka virtual dalam bentuk mahasiswa presentasi, sehingga tidak ada mahasiswa yang tidak menonton video. Dukungan jaringan internet yang baik membuat kelas tatap muka virtual melalui aplikasi zoom meeting berjalan lancar.

Langkah terakhir dari tahap implementasi adalah mahasiswa mengisi kuisioner dan mengerjakan soal tes hasil belajar. Kuisioner diberikan kepada mahasiswa dalam bentuk google form bertujuan untuk mendapatkan respon mahasiswa mengenai proses perkuliahan menggunakan model VFC dan memanfaatkan media video sebagai sumber belajar. Data dari kuisioner dianalisis untuk mengetahui kepraktisan model VFC dan video. Deskripsi hasil analisis kepraktisan disajikan pada Tabel 5. Berdasarkan Tabel 5., diperoleh rata-rata hasil rating model adalah $80,33 \%$ dan ratarata hasil rating video adalah $82,02 \%$. Dengan mengacu pada kriteria Tabel 2., maka dapat dinyatakan model dan media video memenuhi kriteria kepraktisan dengan kategori baik.

Tabel 5. Deskripsi Hasil Rating Kepraktisan Model dan Video

\begin{tabular}{lcc}
\hline \multirow{2}{*}{ Deskripsi } & \multicolumn{2}{c}{ Nilai } \\
& Model pembelajaran & Video pembelajaran \\
\hline Jumlah responden & 16 orang & 16 orang \\
Minimum hasil rating & $77,33 \%$ & $80,00 \%$ \\
Maksimum hasil rating & $82,67 \%$ & $86,15 \%$ \\
Rata-rata hasil rating & $80,33 \%$ & $82,02 \%$ \\
\hline
\end{tabular}

Sumber: diolah dari data penelitian, 2021

Setelah mengisi kuisioner, mahasiswa mengerjakan soal tes hasil belajar. Hasil dari tes digunakan untuk menilai keefektifan model VFC dan media berupa video pembelajaran. Hasil belajar mahasiswa disajikan pada Gambar 3..

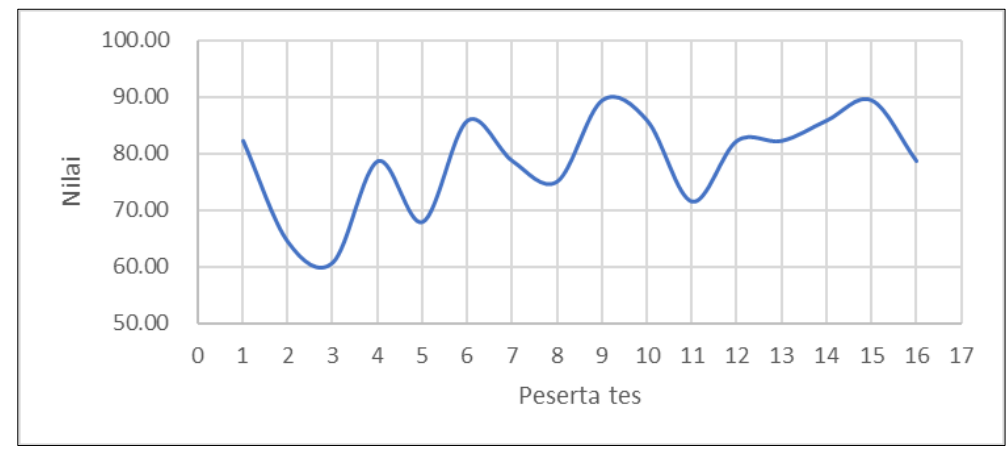

Gambar 3. Hasil Belajar Mahasiswa 
Dari hasil belajar pada Gambar 3. menunjukkan bahwa sebanyak 15 orang mahasiswa memperoleh nilai di atas 61 dan hanya satu mahasiswa yang memperoleh nilai di bawah 61 . Dengan menghitung hasil rating dari hasil belajar diperoleh hasil $93,75 \%$ yang berada pada kategori sangat baik. Dengan demikian dapat dikatakan bahwa model pembelajaran VFC dan penggunaan video sebagai sumber belajar efektif terhadap hasil belajar mahasiswa.

Tahap evaluasi dilakukan untuk memastikan produk yang dikembangkan sudah sesuai dengan yang diharapkan dan tujuan yang ingin dicapai atau perlu direvisi. Kegiatan yang dilakukan meliputi revisi produk (jika ada) dan refleksi implementasi. Hal ini bertujuan untuk menganalisis saran validator serta kendala yang dihadapi mahasiswa dan dosen dalam proses perkuliahan menggunakan model VFC dan media video yang telah dihasilkan. Dari catatan validator menunjukkan media pembelajaran VFC dan video yang telah dihasilkan baik dan tidak ada koreksi yang berarti. Demikian pula, dengan melihat data validitas, praktikalitas dan efektifitas model dan media yang berada pada kategori valid, praktis dan efektif maka model dan media dapat difinalisasi dengan tidak ada revisi.

\section{PEMBAHASAN}

Berdasarkan hasil penelitian dapat dijelaskan bahwa proses perkuliahan di era distrupsi seperti sekarang ini membutuhkan inovasi dan kreatifitas dari dosen dalam merancang dan mengembangkan model, strategi, dan media serta perangkat pembelajaran lain agar tujuan perkuliahan tercapai. Kebutuhan akan rancang bangun model, media dan berbagai perangkat pembelajaran yang cocok hanya dapat diketahui melalui kegiatan evaluasi diri secara sistematis dalam bentuk refleksi mengajar, observasi pembelajaran, diskusi dengan teman sejawat, serta telaah artikel yang relevan. Evaluasi diri dalam proses pembelajaran menjadi pintu masuk bagi instruktur untuk melihat, merasakan, dan memaknai kelebihan dan kekurangan proses pembelajaran untuk selanjutnya melakukan tindak lanjut perbaikan (Brookfield, 2017).

Hasil evaluasi diri dalam proses pembelajaran menunjukkan perlunya inovasi perkuliahan online yang yang bisa menfasilitasi mahasiswa untuk: mengatasi masalah keterbatasan waktu, berprilaku tangguh dan bertanggung jawab terhadap pembelajaran, berpartisipasi aktif, interaktif, komunikatif dan kolaboratif. Sebagai alternatif solusi dirancang suatu model pembelajaran dengan memadukan konsep virtual classroom dan flipped classroom. Salah satu pendekatan pembelajaran matematika yang efisien untuk mencapai pembelajaran aktif dan menyediakan waktu yang cukup serta membuat kemajuan dalam pembelajaran sendiri, baik di dalam maupun di luar kelas adalah flipped classroom (Lopes \& Soares, 2018). Dalam konteks perkuliahan dilakukan secara online sehingga konsep flipped classroom dipadukan dengan konsep virtual classroom. Menggunakan virtual classroom sinkron memberi pelajar kesempatan untuk: berinteraksi dengan instruktur dan pelajar lain, memperoleh umpan balik langsung dari isntruktur, meningkatkan interaksi dinamis dengan peserta lain, memperkuat kehadiran sosial, bertukar dukungan emosional, dan membangun komunikasi (Martin, et. al., 2012). Hasil perpaduan ini dinamakan Virtual Flipped Classroom (VFC). Untuk mendukung performa model VFC dirancang juga video pembelajaran yang akan digunakan sebagai salah satu sumber belajar bagi mahasiswa.

Model dan video yang telah dihasilkan divalidasi terlebih dahulu oleh tim ahli yang merupakan dosen di USN Kolaka sebelum diberlakukan dalam kelas perkuliahan. Hasil validasi menunjukkan bahwa model valid dengan kategori baik dan video valid dengan kategori sangat baik, sehingga layak diujicobakan pada aktifitas perkuliahan secara virtual. Proses perkuliahan dengan model VFC dan memanfaatkan video yang telah dihasilkan berlansung dengan lancar dan mendapat respon positif dari mahasiswa. Hal ini dibuktikan dengan hasil analisis kepraktisan yang menunjukkan model dan media memenuhi kriteria kepraktisan dengan kategori baik. Penggunaan model VFC dan video sebagai sumber belajar juga berdampak positif terhadap hasil belajar. Hal ini terkonfirmasi dari hasil penilaian efektifitas model dan media yang menunjukkan kriteria 
efektif dengan kategori sangat baik. Keterpenuhan aspek validitas, praktikalitas, dan efektifitas model dan media menunjukkan produk berkualitas baik. Nieveen menyatakan bahwa tiga aspek penting dalam menilai kualitas suatu produk perancangan dan pengembangan model, media dan perangkat pembelajaran lain, yaitu valid, praktis dan efektif (Abidin, 2016).

Keefektifan produk dapat dijelaskan karena pada tahap belajar mandiri dari model VFC, dosen memancing inisiatif mahasiswa untuk semangat belajar dan menyimak video yang telah dibagikan dengan membuat tampilan awal video menarik serta menyertakan umpan balik dalam video. Laporan umpan balik dievaluasi pada saat masuk kelas dalam bentuk mahasiswa presentasi yang dilanjutkan dengan tanya jawab dan diskusi. Dengan demikian mau tidak mau mahasiswa tetap perlu menyimak video agar dapat presentasi di kelas. Hal ini dapat menumbuhkan budaya tangguh dan bertanggung jawab terhap pembelajaran baik di kelas maupun di luar kelas, serta melatih keterampilan komunikasi dan kolaborasi.

\section{SIMPULAN}

Produk yang dihasilkan dari penelitian dan pengembangan ini berupa model pembelajaran Virtual Flipped Classroom (VFC) dan video pembelajaran. Model dan media yang dihasilkan sesuai dengan kebutuhan mahasiswa dan berperan sebagai alternatif solusi dalam perkuliahan online yang tidak monoton. Validitas produk berdasarkan hasil evaluasi dari dua ahli diperoleh valid. Mahasiswa memberikan respon positif terhadap proses perkuliahan dengan model VFC dan pemanfaatan video sebagai sumber belajar. Hasil analisis praktikalitas diperoleh produk praktis. Demikian juga dengan penilaian pada aspek efektfitas, hasil perhitungan menunjukkan produk efektif dengan kategori sangat baik. Video pembelajaran yang berisi tujuan, materi pengajaran dan umpan balik yang dimanfaatkan dalam proses perkuliahan dengan pendekatan VFC dapat menggugah semangat mahasiswa untuk belajar, menumbuhkan rasa tanggung jawab terhadap pembelajaran sendiri, serta melatih komunikasi dan kolaborasi yang pada akhirnya dapat berdampak positif terhadap capaian hasil belajar. Hasil penelitian ini memberikan rekomendasi untuk menguji keefektifan model pada topik dan kelas yang lain.

\section{UCAPAN TERIMA KASIH}

Ucapan terima kasih kami sampaikan kepada Direktorat Riset dan Pengabdian Masyarakat Kementerian Pendidikan, Kebudayaan, Riset dan Teknologi yang telah mendukung pelaksanaan penelitian ini secara moril berupa motivasi dan materil berupa bantuan pendanaan. Ucapan terima kasih juga kami sampaikan kepada Universitas Sembilanbelas November Kolaka terkhusus Lembaga Pelaksanaan dan Penjaminan Mutu yang telah memfasilitasi penelitian ini mulai dari penyusunan proposal sampai pada pelaksanaan penelitian.

\section{DAFTAR PUSTAKA}

Abidin, Z. (2016). PENGEMBANGAN MODEL PEMBELAJARAN MATEMATIKA BERBASIS PORTOFOLIO (PMBP) PADA SISWA SEKOLAH MENENGAH PERTAMA. JPM : Jurnal Pendidikan Matematika, 2(1). https://doi.org/10.33474/jpm.v2i1.209

Aldoobie, N. (2015). ADDIE Model Analysis phase. American International Journal of Contemporary Research, 5(6).

Arbain, A., \& Farman, F. (2021). Pembelajaran Daring Masa Darurat Covid-19 Pada Mahasiswa Pendidikan Matematika. HISTOGRAM: Jurnal Pendidikan Matematika, 4(2). https://doi.org/10.31100/histogram.v4i2.720

Brookfield, S. (2017). Becoming a critically reflective teacher second edition. Becoming a Critically Reflective Teacher Second Edition, Brookfield. 
Chandra, F. H., \& Nugroho, Y. W. (2016). Peran teknologi dalam flipped classroom. Jurnal Ilmiah Teknologi Dan Rekayasa, 8(1).

Dhawan, S. (2020). Online Learning: A Panacea in the Time of COVID-19 Crisis. Journal of Educational Technology Systems. https://doi.org/10.1177/0047239520934018

Feriatna, T., Pramuditya, S. A., \& Aminah, N. (2017). PENGEMBANGAN APLIKASI ANDROID SEBAGAI MEDIA PEMBELAJARAN MATEMATIKA PADA MATERI PELUANG UNTUK SISWA SMA KELAS X. LEMMA, IV(1), 65-75.

Firman, F., \& Rahayu, S. (2020). Pembelajaran Online di Tengah Pandemi Covid-19. Indonesian Journal of Educational Science (IJES). https://doi.org/10.31605/ijes.v2i2.659

Gonzalez, T., De la Rubia, M. A., Hincz, K. P., Comas-Lopez, M., Subirats, L., Fort, S., \& Sacha, G. M. (2020). Influence of COVID-19 confinement on students' performance in higher education. PLoS ONE, 15(10 October). https://doi.org/10.1371/journal.pone.0239490

Gümüş, S. (2010). Rapid content production and delivery in e-learning environments: Use of Adobe Presenter, MS Powerpoint, Adobe Connect. Procedia - Social and Behavioral Sciences, 9. https://doi.org/10.1016/j.sbspro.2010.12.238

Hartono, H., \& Irvandi, W. (2021). Pengembangan metode pembelajaran halaqah berbasis etnomatematika untuk memahamkan penyelesaian masalah transportasi kelas program linier. Pythagoras: Jurnal Pendidikan Matematika, 15(2). https://doi.org/10.21831/pg.v15i2.36432

Hodges, C., Moore, S., Lockee, B., Trust, T., \& Bond, A. (2020). The Difference Between Emergency Remote Teaching and Online Learning. Educause.

Lai, C. L., \& Hwang, G. J. (2016). A self-regulated flipped classroom approach to improving students' learning performance in a mathematics course. Computers and Education. https://doi.org/10.1016/j.compedu.2016.05.006

Lee, W. W., \& Owens, D. L. (2012). Multimedia-Based Instructional Design. In Pfeiffer: Vol. XXXIII (Issue 2).

Lo, C. K., Hew, K. F., \& Chen, G. (2017). Toward a set of design principles for mathematics flipped classrooms: A synthesis of research in mathematics education. Educational Research Review, 22, 50-73. https://doi.org/10.1016/j.edurev.2017.08.002

Lopes, A. P., \& Soares, F. (2018). Perception and performance in a flipped Financial Mathematics classroom. International Journal of Management Education, 16(1), 105-113. https://doi.org/10.1016/j.ijme.2018.01.001

Martin, F., Parker, M. A., \& Deale, D. F. (2012). Examining interactivity in synchronous virtual classrooms. International Review of Research in Open and Distance Learning, 13(3). https://doi.org/10.19173/irrodl.v13i3.1174

Mishra, D. L., Gupta, D. T., \& Shree, D. A. (2020). Online Teaching-Learning in Higher Education during Lockdown Period of COVID-19 Pandemic. International Journal of Educational Research Open. https://doi.org/10.1016/j.ijedro.2020.100012

Mulyatna, F., Imswatama, A., \& Rahmawati, N. D. (2021). Design Ethnic-Math HOTS: Mathematics Higher Order Thinking Skill Questions Based On Culture and Local Wisdom. Malikussaleh Journal of Mathematics Learning (MJML), 4(1), 48. https://doi.org/10.29103/mjml.v4i1.3059

Murphy, M. P. A. (2020). COVID-19 and emergency eLearning: Consequences of the securitization of higher education for post-pandemic pedagogy. Contemporary Security Policy. https://doi.org/10.1080/13523260.2020.1761749

Patricia, A. (2020). College Students' Use and Acceptance of Emergency Online Learning Due to COVID-19. International Journal of Educational Research Open. https://doi.org/10.1016/j.ijedro.2020.100011

Ridha, M., Setyosari, P., \& Kuswandi, D. (2016). Pengaruh Flipped Mastery Classrom Terhadap Perolehan Hasil Belajar Kognitif Mahasiswa. In Jurnal Pendidikan (Vol. 1, Issue 4).

Saunders, J. M. (2014). The flipped classroom: Its effect on student academic achievement and 
critical thinking skills in high school mathematics. ProQuest Dissertations and Theses. Sugiyono, S. (2017). Metode Penelitian Kuantitatif, Kualitatif dan R\&D. Bandung: Alfabeta.

Sun, J. C. Y., Wu, Y. T., \& Lee, W. I. (2017). The effect of the flipped classroom approach to OpenCourseWare instruction on students' self-regulation. British Journal of Educational Technology, 48(3). https://doi.org/10.1111/bjet.12444

Szarek, J. L., Boardman, J. M., White, M., \& Holt, J. T. (2016). Integrated and Flipped: 5 Years' Experience of Integrating Active Learning in an Integrated Course. Medical Science Educator, 26(1). https://doi.org/10.1007/s40670-015-0214-7

Thomson, D. L. (2010). Beyond the Classroom Walls: Teachers' and Students' Perspectives on How Online Learning Can Meet the Needs of Gifted Students. Journal of Advanced Academics, 21(4). https://doi.org/10.1177/1932202X1002100405

Wiratomo, Y., \& Mulyatna, F. (2020). Use of Learning Management Systems in Mathematics Learning during a Pandemic. Journal of Mathematical Pedagogy (JoMP), 1(2), 62-71. https://doi.org/https://doi.org/10.26740/jomp.v1n2.p\%25p 
134 Arbain \& Salim 